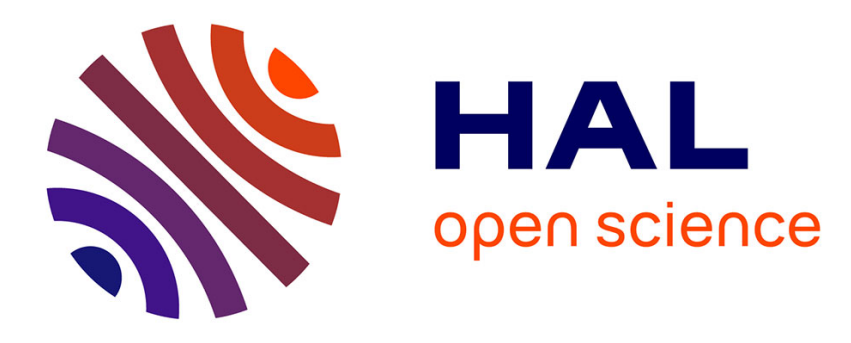

\title{
Applying a typology of management accounting change: A research note
}

Tarek Chanegrih

\section{To cite this version:}

Tarek Chanegrih. Applying a typology of management accounting change: A research note. Management Accounting Research, 2008, 19 (3), pp.278-285. 10.1016/j.mar.2008.06.005 . hal-02364761

\section{HAL Id: hal-02364761}

\section{https://hal-normandie-univ.archives-ouvertes.fr/hal-02364761}

Submitted on 25 Nov 2019

HAL is a multi-disciplinary open access archive for the deposit and dissemination of scientific research documents, whether they are published or not. The documents may come from teaching and research institutions in France or abroad, or from public or private research centers.
L'archive ouverte pluridisciplinaire $\mathbf{H A L}$, est destinée au dépôt et à la diffusion de documents scientifiques de niveau recherche, publiés ou non, émanant des établissements d'enseignement et de recherche français ou étrangers, des laboratoires publics ou privés. 


\section{Applying a typology of management accounting change: A research note}

Tarek CHANEGRIH

Laboratoire NIMEC - IAE Caen

\section{Introduction}

Since advocacy by Hopwood (1983) in Europe and Kaplan (1983) in the USA, the study of change in management accounting control systems (MACS) has become an increasingly popular research topic. Using a range of methods, researchers have examined the motivations, constraints and consequences of change in management accounting (MA) (e.g. Innes and Mitchell, 1990; Scapens and Roberts, 1993; Ezzamel, 1994; Malmi, 1997; Vaivio, 1999; Burns and Scapens, 2000; Granlund, 2001; Lukka, 2007). Yet researchers largely neglected identification of the volume and location of MA change until Libby and Waterhouse (1996). Moreover, the nature of change has frequently been taken for granted by researchers (Quattrone and Hopper, 2001). Sulaiman and Mitchell (2005) were the first to develop a typology of change in MA (addition, replacement, output modification, operational modification and reduction) in order to study both its nature and location. The results of their research in Malaysian companies show that various types of change are represented in all MA sub-systems, with the exception of MA reduction, which was not observed in any of the companies surveyed.

The purpose of this research is to replicate and extend S and M's study in French manufacturing companies. Similar results are evident in the location and nature of change although some differences are apparent, which can be explained by national cultures and macroeconomic factors. Two extensions to $\mathrm{S}$ and $\mathrm{M}$ are also introduced. First, this study refines $\mathrm{S}$ and $\mathrm{M}$ 's typology by separating output modification into two dimensions, information representation changes and information frequency changes. We find it relevant to separate changes in information frequency, which are required for rapid responses in the face of greater competition (Gordon and Miller, 1976), 
from changes in the representation of information, which are introduced to improve internal communication (Moores and Yven, 2001). This extension enhances examination of the heterogeneous nature of change in MA. Second, this study sets out to examine the factors contributing to the success of the changes made. We especially want to assess top management support (Innes and Mitchell, 1991; Shields, 1995; Innes and Mitchell, 1995; Krumwiede, 1998; Innes et al., 2000), the level of complexity/simplification (Sulaiman and Mitchell, 2005), and the degree of resistance to change (Johnson and Kaplan, 1987; Argyris and Kaplan, 1994; Shields, 1995).

\section{Empirical analysis}

\subsection{Data collection}

The study was designed to compare our findings with those of Libby and Waterhouse (1996) in Canada, Williams and Seaman (2001) in Singapore and Sulaiman and Michell (2005) in Malaysia. After advance testing with controllers and financial officers, our questionnaire was sent in March 2006 to a sample of 320 manufacturing companies with more than 100 employees, to conform to the L and W (1996) and W and S (2001) ${ }^{1}$ sample selection criteria. After two follow-up letters and calls, 74 replies were obtained. One firm was eliminated as it has fewer than 100 employees. Two respondents with less than four (4) years of service in their positions were also discarded, as were six (6) incomplete questionnaires. This yielded a final aggregate sample of 65 firms, or a $20 \%$ response rate for the study. A profile of the final sample is given in table $1.66 \%$ of respondents are controllers, $30 \%$ are chief financial officers and $4 \%$ are plant managers. $78 \%$ of companies that responded to the questionnaire belong to a group. The existence of possible response bias between the early and late responses was checked by a t-test: no significant differences were found in the

\footnotetext{
${ }^{1}$ No size constraint was indicated in the study conducted in Malaysia.
} 
results. Furthermore, the t-test reveals no significant differences in terms of size between respondents and non-respondents.

Table 1 Profile of sample firms

\begin{tabular}{|c|c|c|c|c|}
\hline $\begin{array}{c}\text { Number of } \\
\text { employees }\end{array}$ & $\begin{array}{c}\text { Number of firms } \\
\text { (France) }\end{array}$ & $\%$ (France) & $\%$ (Singapore) & $\%$ (Canada) \\
\hline $0-149$ & 10 & 15.38 & 27.95 & 33.33 \\
\hline $150-299$ & 24 & 36.92 & 27.95 & 29.16 \\
\hline $300-499$ & 11 & 16.92 & 11.82 & 16.66 \\
\hline $450-999$ & 10 & 15.38 & 16.12 & 4.16 \\
\hline$>1000$ & 10 & 15.38 & 16.12 & 16.66 \\
\hline Total & 65 & 100 & 100 & 100 \\
\hline
\end{tabular}

\subsection{Results regarding change location}

Table 2 reveals that the average annual number of changes in French companies (1.40) was higher than in Singaporean companies (1.23) but lower than in Canadian companies (1.48) and Malaysian companies (1.90). Although the average annual number of changes and their distribution between location vary, change locations are broadly similar: controlling, decision-making and planning comprise the top 3 in all four studies. Costing and directing therefore appear to be the slowestchanging sub-systems despite the prominence of costing innovations such as ABC, life cycle costing and quality costing. This confirms that new costing models spread slowly in France (Mévellec, 2003).

\subsection{Results regarding the nature of change}

The significant responses accorded to both information frequency and information representation changes (table 3) provide justification for the refinement made to S and M's typology (2005). Apart from the general similarities in the nature and location of MA change, three major differences are noteworthy. First, addition and replacement are contrastingly distributed. French companies seem to favour extending MACS by introducing new techniques, whereas Malaysian companies prefer to 
replace techniques. Second, despite the very low scores for reduction, this type of change is observed in France, but in none of the Malaysian companies. Third, the number of French companies that made no changes is high compared to Malaysian companies. 
Table 2 The location of change in different countries

(This study, France, 2002-2005) $\mathrm{N}=65$; response rate $=20 \%$
(Sulaiman and Mitchell, Malaysia, 1997-2001) $\mathrm{N}=92$; response rate $=\mathbf{2 9 \%}$
(Libby and Waterhouse, Canada, 1991-1993) $\mathrm{N}=24$; response rate $=34 \%$
(Williams and Seaman, Singapore, 1995-1997) $\mathrm{N}=93$; response rate $=45 \%$

\begin{tabular}{|c|c|c|c|c|c|c|c|c|c|c|c|c|c|c|c|c|c|c|c|c|c|}
\hline & $\begin{array}{l}\text { Number } \\
\text { of } \\
\text { changes }\end{array}$ & $\begin{array}{l}\text { Average } \\
\text { number } \\
\text { of annual } \\
\text { changes }\end{array}$ & $\begin{array}{l}\text { External } \\
\text { ranking }\end{array}$ & $\%$ & $\begin{array}{l}\text { Internal } \\
\text { ranking }\end{array}$ & $\begin{array}{l}\text { Number } \\
\text { of } \\
\text { changes }\end{array}$ & $\begin{array}{c}\text { Average } \\
\text { number of } \\
\text { annual } \\
\text { change }\end{array}$ & $\begin{array}{l}\text { External } \\
\text { ranking }\end{array}$ & $\%$ & $\begin{array}{l}\text { Number } \\
\text { of } \\
\text { changes }\end{array}$ & $\begin{array}{l}\text { Internal } \\
\text { ranking }\end{array}$ & $\begin{array}{l}\text { Number } \\
\text { of } \\
\text { changes }\end{array}$ & $\begin{array}{l}\text { Average } \\
\text { number } \\
\text { of annual } \\
\text { changes }\end{array}$ & $\begin{array}{l}\text { External } \\
\text { ranking }\end{array}$ & $\%$ & $\begin{array}{l}\text { Internal } \\
\text { ranking }\end{array}$ & $\begin{array}{l}\text { Number } \\
\text { of } \\
\text { changes }\end{array}$ & $\begin{array}{c}\text { Average } \\
\text { number } \\
\text { of annual } \\
\text { changes }\end{array}$ & $\begin{array}{l}\text { External } \\
\text { ranking }\end{array}$ & $\%$ & $\begin{array}{l}\text { Internal } \\
\text { ranking }\end{array}$ \\
\hline Controlling & 103 & 0.40 & 3 & 28.38 & 1 & 221 & 0.48 & 1 & 25.3 & 32 & 2 & 32 & 0.44 & 2 & 29.9 & 2 & 80 & 0.28 & 4 & 23.25 & 3 \\
\hline Decision-making & 82 & 0.32 & 4 & 22.58 & 2 & 191 & 0.42 & 2 & 21.8 & 34 & 3 & 34 & 0.47 & 1 & 31.8 & 1 & 93 & 0.33 & 3 & 27.03 & 1 \\
\hline Planning & 68 & 0.26 & 3 & 18.74 & 3 & 241 & 0.52 & 1 & 27.5 & 17 & 1 & 17 & 0.24 & 4 & 15.9 & 3 & 87 & 0.31 & 2 & 25.29 & 2 \\
\hline Costing & 63 & 0.24 & 2 & 17.35 & 4 & 162 & 0.35 & 1 & 18.5 & 13 & 4 & 13 & 0.18 & 3 & 12.1 & 4 & 34 & 0.12 & 4 & 9.83 & 5 \\
\hline Directing & 47 & 0.18 & 2 & 12.95 & 5 & 60 & 0.13 & 4 & 6.9 & 11 & 5 & 11 & 0.15 & 3 & 10.3 & 5 & 50 & 0.19 & 1 & 14.53 & 4 \\
\hline Total & 363 & 1.40 & 3 & 100 & & 875 & 1.90 & 1 & 100 & 107 & & 107 & 1.48 & 2 & 100 & & 344 & 1.23 & 4 & 100 & \\
\hline
\end{tabular}

$\mathrm{N}$ : number of respondents 
Table 3 The nature of change in France and Malaysia

(This study, France)

\begin{tabular}{|c|c|c|c|c|c|c|c|c|c|c|c|c|c|}
\hline & & & & & & is study, & rance) & & & & & & \\
\hline \multirow[t]{2}{*}{$\begin{array}{l}\text { (1) Change type } \\
\text { frequency and } \\
\text { location }\end{array}$} & \multicolumn{2}{|c|}{ Addition } & \multicolumn{2}{|c|}{ Replacement. } & \multicolumn{2}{|c|}{$\begin{array}{c}\text { Information } \\
\text { frequency change }\end{array}$} & \multicolumn{2}{|c|}{$\begin{array}{c}\text { Information } \\
\text { representation } \\
\text { change }\end{array}$} & \multicolumn{2}{|c|}{$\begin{array}{l}\text { Operational } \\
\text { modification }\end{array}$} & \multicolumn{2}{|c|}{ Reduction } & \multirow[t]{2}{*}{ Total } \\
\hline & $\mathrm{N}$ & $\%$ & $\mathrm{~N}$ & $\%$ & $\mathrm{~N}$ & $\%$ & $\mathrm{~N}$ & $\%$ & $\mathrm{~N}$ & $\%$ & $\mathrm{~N}$ & $\%$ & \\
\hline Controlling & 36 & 35.0 & 9 & 8.7 & 27 & 26.2 & 22 & 21.4 & 9 & 8.7 & 0 & 0.0 & 103 \\
\hline Decision-making & 35 & 42.7 & 6 & 7.3 & 17 & 20.7 & 18 & 22.0 & 5 & 6.1 & 1 & 1.2 & 82 \\
\hline Planning & 24 & 35.4 & 10 & 14.8 & 12 & 17.6 & 15 & 22.1 & 6 & 8.8 & 1 & 1.3 & 68 \\
\hline Costing & 17 & 27.0 & 9 & 14.3 & 5 & 7.9 & 7 & 11.1 & 24 & 38.1 & 1 & 1.6 & 63 \\
\hline Total & 128 & 35.3 & 44 & 12.1 & 69 & 19.0 & 71 & 19.6 & 47 & 12.9 & 4 & 1.1 & 363 \\
\hline Rank 1 & 1 & & 5 & & 3 & & 2 & & 4 & & 6 & & \\
\hline Total & 128 & 35.3 & 44 & 12.1 & 140 & & & 38.6 & 47 & 12.9 & 4 & 1.1 & \\
\hline Rank 2 & & & & 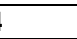 & & & 1 & & & & & 5 & \\
\hline
\end{tabular}

(Sulaiman and Mitchell, Malaysia)

\begin{tabular}{|c|c|c|c|c|c|c|c|c|c|c|c|}
\hline \multirow{2}{*}{$\begin{array}{l}\text { (1) Change type } \\
\text { frequency and } \\
\text { location }\end{array}$} & \multicolumn{2}{|c|}{ Addition } & \multicolumn{2}{|c|}{ Replacement. } & \multicolumn{2}{|c|}{ Output modification } & \multicolumn{2}{|c|}{$\begin{array}{l}\text { Operational } \\
\text { modification }\end{array}$} & \multicolumn{2}{|c|}{ Reduction } & \multirow[t]{2}{*}{ Total } \\
\hline & $\mathrm{N}$ & $\%$ & $\mathrm{~N}$ & $\%$ & $\mathrm{~N}$ & $\%$ & $\mathrm{~N}$ & $\%$ & $\mathrm{~N}$ & $\%$ & \\
\hline Controlling & 31 & 14.3 & 89 & 40.3 & \multirow{6}{*}{$\begin{array}{l}68 \\
73 \\
101 \\
67 \\
17 \\
326\end{array}$} & \multirow{6}{*}{$\begin{array}{l}30.8 \\
38.2 \\
41.9 \\
41.4 \\
28.3 \\
37.3\end{array}$} & 33 & 14.6 & - & - & 221 \\
\hline Decision-making & 27 & 14.1 & 74 & 38.7 & & & 17 & 9.0 & - & - & 191 \\
\hline Planning & 34 & 14.1 & 80 & 33.2 & & & 26 & 10.8 & - & - & 241 \\
\hline Costing & 25 & 15.4 & 49 & 30.2 & & & 21 & 13.0 & - & - & 162 \\
\hline Directing & 5 & 8.3 & 33 & 55 & & & 5 & 8.4 & - & - & 60 \\
\hline Total & 122 & 13.9 & 325 & 37.1 & & & 102 & 11.7 & - & - & 875 \\
\hline Rank & & 3 & & 2 & & & & & \multicolumn{2}{|c|}{5} & \\
\hline
\end{tabular}

\begin{tabular}{|c|c|c|c|}
\hline $\begin{array}{c}\text { (2) Number of change } \\
\text { types experienced }\end{array}$ & $\begin{array}{c}\text { Number of responding companies } \\
\text { experiencing this number of change types } \\
\text { (This study, France) }\end{array}$ & $\begin{array}{c}\text { Number of responding companies } \\
\text { experiencing this number of change types } \\
\text { (S and M, Malaysia) }\end{array}$ & $\begin{array}{c}\text { \% } \\
\%\end{array}$ \\
\hline 0 & 8 & 12.30 & 23 \\
\hline 1 & 19 & 29.23 & 34 \\
\hline 2 & 19 & 29.23 & 25 \\
\hline 3 & 13 & 20.00 & 37 \\
\hline 4 & 5 & 7.70 & 25 \\
\hline 5 & 1 & 1.54 & - \\
\hline Total & 65 & 100 & \\
\hline
\end{tabular}

\subsection{Results regarding change management}

Table 4 shows the relatively low degree of resistance to change compared to the top management support and level of complexity. It also indicates that top management support and level of complexity score highest for the introduction of new techniques (addition and replacement). Operational modifications are the least important type of change and show the lowest degree of top management support. The introduction of new techniques, such as replacement or extension, is the most important and successful form of change within the responding companies. 
Table 4 Average change management scores

\begin{tabular}{|l|c|c|c|c|c|}
\hline & Importance & Success & $\begin{array}{c}\text { Top manageme } \\
\text { support }\end{array}$ & $\begin{array}{c}\text { Level of } \\
\text { complexity }\end{array}$ & Resistance to change \\
\hline Addition & $1.45^{2}$ & 1.75 & 1.81 & 1.03 & 0.44 \\
\hline Replacement & 1.64 & 1.58 & 1.58 & 1.35 & 0.50 \\
\hline $\begin{array}{l}\text { Information frequency } \\
\text { change }\end{array}$ & 1.24 & 1.35 & 1.48 & 0.72 & 0.51 \\
\hline $\begin{array}{l}\text { Information } \\
\text { representation change }\end{array}$ & 1.10 & 1.00 & 1.51 & 0.79 & 0.46 \\
\hline $\begin{array}{l}\text { Operational } \\
\text { modification }\end{array}$ & 1.04 & 1.08 & 1.38 & 0.92 & - \\
\hline Reduction $^{3}$ & - & - & - & - & 0.56 \\
\hline
\end{tabular}

Pearson's matrix (table 5) indicates that importance and success are correlated. A smaller degree of correlation is observed between the level of complexity and importance, top management support and success, and top management support and the degree of resistance to change.

Table 5 Pearson's correlation matrix

\begin{tabular}{|l|l|l|l|l|}
\hline & Success & $\begin{array}{l}\text { Top management } \\
\text { support }\end{array}$ & Level of complexity & Resistance to change \\
\hline Importance & $0.873^{* *}$ & 0.656 & $0.817^{*}$ & -0.372 \\
\hline Success & $0.829^{*}$ & 0.594 & -0.43809 \\
\hline $\begin{array}{l}\text { Top management } \\
\text { support }\end{array}$ & & 0.377 & $-0.825^{*}$ \\
\hline $\begin{array}{l}\text { Level of complexity } \\
* * \mathrm{p}<0.05 * \mathrm{p}<0.1\end{array}$ & & & -0.046 \\
\hline
\end{tabular}

\section{Discussion}

\subsection{Discussion on location results}

The consistently low ranking of costing systems in all the studies is suggestive of a widespread lack of practical interest in high profile developments such as ABC (Innes and Mitchell, 1995; Lukka and Granlund, 1996; Israelsen et al., 1996; Ask et al., 1996; Sherrer, 1996; Gosselin, 1997; Chenhall and Langfield-Smith, 1998; Malmi, 1999; Innes et al., 2000; Mévellec, 2003).

Differences in the overall annual rates of change are apparent. They may be caused by macroeconomic circumstances. Companies operating in a difficult economic context are under pressure to improve efficiency. This creates internal demand for MA information with a resulting tendency to change MA techniques more frequently (Williams and Seaman, 2001). The annual

\footnotetext{
${ }^{2}$ Average ratings based on a three-point Likert scale ( $0=$ low, $1=$ medium, $2=$ high).

${ }^{3}$ Due to its extremely low scores, reduction is left out of the following analyses.
} 
number of changes is therefore much higher in Malaysia than in any other country. The Asian exchange rate crisis offers a justification for this pattern of results (Sulaiman and Mitchell, 2005). Ontario, where the Canadian study took place, suffered an economic recession between 1991 and 1993 and this may account for its second ranking in volume of change. France, with lethargic economic growth during the study period, ranks third. The relatively low number of changes in Singapore could be explained by the fact that Singaporean companies, in a high economic growth environment, had little incentive to prioritize changes in MA.

It is also apparent that the rank of the average number of changes in each type of location varies. For example, controlling systems rank first in France, second in Malaysia and Canada but only third in Singapore. Controlling system changes included changes in the way performance was measured at the individual and organizational levels, as well as changes in performance evaluation in terms of quality and customer service. It is possible that France ranks first in controlling systems because of cultural dimensions (Hofstede, 1980, 1991). In terms of cultural profile, France has the highest score in uncertainty avoidance (table 6). Low tolerance for ambiguity could prompt companies to reduce uncertainty avoidance through controlling. This hypothesis is reinforced by the fact that Singaporean companies, with their high tolerance for ambiguity, have the lowest rank for controlling (in the top three types of location), and that Malaysian and Canadian companies, which have medium tolerance for ambiguity, occupy medium rankings in controlling. In addition, it can be argued that decision-making systems rank second in this study because the need for rapid responses grows as competition intensifies, and most of the respondents (78\% of questionnaire respondents) were subsidiaries of larger groups in which internal reporting is required. Planning systems rank third in France. Canadian (table 6) and French companies tend to a short-term view and this could explain why the companies in these two countries do not appear to prioritize changes in this area. In contrast, Malaysian and Singaporean companies, closer to Chinese culture and thus taking a longer-term view, respectively rank first and second in planning systems. 
Table 6 Cultural cues in the four countries

\begin{tabular}{|l|l|l|l|l|l|}
\hline & Power distance & $\begin{array}{l}\text { Uncertainty } \\
\text { avoidance }\end{array}$ & Individualism/collectivism & $\begin{array}{l}\text { Masculinity/ } \\
\text { femininity }\end{array}$ & $\begin{array}{l}\text { Confucian } \\
\text { dynamism }\end{array}$ \\
\hline France & 68 & 86 & 71 & 43 & - \\
\hline Malaysia & 104 & 36 & 26 & 50 & - \\
\hline Singapore & 74 & 8 & 20 & 48 & 48 \\
\hline Canada & 39 & 48 & 80 & 52 & 23 \\
\hline Mean & 57 & 65 & 43 & 49 & \\
\hline
\end{tabular}

Source: Hofstede, 1980, 1991.

\subsection{Discussion on the nature of change}

The results of this study regarding information representation change and information frequency change validate the refinement made to $S$ and M's typology by enhancing examination of the heterogeneous nature of change.

Three differences should be noted. First, reduction was not observed in any Malaysian company, whereas four French companies removed a MA technique. This difference could be explained by the degree of individualism/collectivism in the country's culture. Collectivist cultures, which tend to think in terms of "we" instead of "I", emphasize harmony (Hofstede, 1980) and eliminating techniques introduced by other people can create tensions within the company. Power distance (Hofstede, 1980), which is especially high in Malaysia, could reinforce this result if the persons who introduced the techniques has a high-responsibility job. Indeed, the proportion of French companies which made no change is much higher than that of Malaysian companies. This may result from the macroeconomic context. More intensely competitive environments may have led Malaysian companies to change MA techniques (Libby and Waterhouse, 1996). Finally, French companies introduced three times more replacement, whereas Malaysian companies introduced three times more addition. The degree of individualism/collectivism (Hofstede, 1980) could explain why French companies are more inclined to add innovative solutions to existing systems. Managers in collectivist cultures pay little attention to new or fashionable management ideas, whereas managers in individualistic cultures keep up to date with new ideas and try to put them into practice 
(Hofstede, 1980). In individualistic cultures, strength comes from initiative and personal achievements.

Although French companies seem to carry out more radical changes than Malaysian companies, incremental changes (replacement, output modification and operational modification) clearly predominate in both countries. The general MA framework is preserved over time, and changes seem to be more an evolution than a revolution (Bromwich and Bhimani, 1989). These results corroborate recent studies which see MA change as a relatively slow process of change in organizational routines and rules (Scapens, 1994; Burns and Scapens, 2000).

\subsection{Discussion on change management}

The degree of resistance to change was low. Strong support from top management is one factor likely to contribute to the level of resistance. Operational modifications score lowest in top management support, probably because of the purely technical nature of this type of change. The introduction of new techniques is the most important and successful type of change. The correlation matrix indicates that management heavily influences the most important and apparently most complex changes and this support lowers the degree of resistance to change.

\subsection{Overall}

This study confirms that MA is a practice which exhibits extensive and consistent change. It also shows that while many aspects of the volume and pattern of that change show consistency across countries and continents there are notable differences which can be attributed to economic circumstances and cultural differences.

\section{Acknowledgments}

I would like to thank Professor Robert Scapens and two anonymous reviewers for their constructive comments. 


\section{References}

Ask, U., Ax, C. and Jonsson, S. (1996) Cost Management in Sweden: from Modern to Post-Modern, in A. Bhimani (eds) Management Accounting: European Perspectives, Oxford University Press, pp.199-217.

Argyris, C and Kaplan, R.S. (1994) Implementing new knowledge: the case of activity-based costing, Accounting Horizons, 8 (3), pp, 83-105.

Bromwich, M. and Bhimani, A. (1989) Management accounting: evolution not revolution, Chartered Institute of Management Accountants.

Burns, J. and Scapens, R. (2000) Conceptualising Management Accounting Change: an Institutional Framework, Management Accounting Research, 11, pp. 3-25.

Chenhall, R.H. and Langfield-Smith, K. (1998) Adoption and Benefits of Management Accounting Practices: An Australian study, Management Accounting Research, 9, pp. 1-20.

Ezzamel, M. (1994) Organisational change and accounting: understanding the budgeting system in its organisational context, Organisational studies, 15, pp. 213-240.

Gordon, L.A. and Miller, D. (1976) A Contingency Framework for the Design of Accounting Information Systems, Accounting, Organization and Society, vol. 9, n¹, pp.33-47.

Gosselin, M. (1997) The Effect of Strategy and Organisational Structure on the Adoption and Implementation of Activity Based Costing, Accounting, Organization and Society, 22, pp. 105-122.

Granlund, M. (2001) Towards explaining stability in and around management accounting systems, Management Accounting Research, 12, pp. 141-166.

Hofstede, G.H. (1980) Culture's consequences: international differences in work-related values, Beverly Hills: Sage publications.

Hofstede, G.H, (1991) Cultures and organizations: software of the mind, New York: Mc Graw-Hill.

Hopwood, A. (1983) On Trying to study accounting in the context in which it operates, Accounting, Organization and Society, 8, pp.287-305.

Innes, J., Mitchell, F. and Sinclair, D. (2000) Activity Based Costing in the UK's largest companies: a comparison of 1994 and 1999, Management Accounting Research, 11, pp. 349-362.

Innes, J. and Mitchell, F. (1991) Activity Based Costing: A Survey of CIMA Members, Management Accounting, October, pp. 28-30.

Innes, J. and Mitchell, F. (1995) Activity Based Costing In The UK's Largest Companies, Management Accounting Research, 6, 2, pp. 137-153.

Innes, J. and Mitchell, F. (1990) The process of change in management accounting: some field study evidence, Management Accounting Research, 1, p. 3-19.

Israelsen, P., Anderson, M., Rohde, C. and Sorensen, P.E. (1996) Management Accounting in Denmark: Theory and Practice, in A. Bhimani (eds) Management Accounting: European Perspectives, Oxford University Press, pp. 31-53.

Johnson, H.T. and Kaplan, R.S. (1987) Relevance lost: the rise and the fall of management accounting, Harvard Business School Press.

Kaplan, R.S. (1983) Measuring Manufacturing Performance: A New Challenge for Management Accounting Research, The Accounting Review, pp. 686-705.

Krumwiede, K.R., (1998) The implementation of activity-based costing and the impact of contextual and organizational factors, Journal of Management Accounting research, 10, 239-277.

Libby, T. and Waterhouse, J. (1996) Predicting Change in Management Accounting Systems, Journal of Management Accounting Research, pp. 137-150.

Lukka, K. and Granlund, M. (1996) Cost Accounting in Finland: Current Practice and Trends of Development, European Accounting Review, 5, pp. 1-28

Lukka, K. (2007) Management accounting change and stability: loosely coupled rules and routines in action, Management Accounting Research, 18, pp. 76-101.

Malmi, T. (1997) Towards explaining activity-based costing failure: accounting and control in a decentralised organisation, Management Accounting Research, 8, pp. 459-480.

Malmi, T. (1999) Activity-based costing diffusion across organizations: an exploratory empirical analysis of Finnish firms, Accounting, Organization and society, 24 (8), 649-672.

Mévellec, P. (2003) Les paramètres de conception des systèmes de coûts, étude comparative, Comptabilité Contrôle Audit, mai, 1, pp. 95-110.

Moores, K. and Yuen, S. (2001) Management Accounting Systems and Organizational Configuration: A Life Cycle Perspective, Accounting, Organization and Society, 26, pp. 351-389.

Quattrone, P. and Hopper, T. (2001) What Does Organisational Change Mean? Speculations on a Taken For Granted Category, Management Accounting Research, 12, pp. 403-435.

Scapens, R.W. (1994) Never Mind the Gap: Towards an Institutional Perspective On Management Accounting Practice, Management Accounting Research, 5, pp. 301-321.

Scapens, R.W. and Roberts, J. (1993) Accounting and control: a case study of resistance to accounting change, Management Accounting Research, 4, pp. 1-32. 
Scherrer, G. (1996) Management Accounting: a German Perspectives, in A. Bhimani (eds) Management Accounting: European Perspectives, Oxford University Press, pp. 100-122.

Shields, M.D. (1995) An empirical analysis of firms' implementation experiences with activity-based costing. Journal of Management Accounting Research, 7, pp. 148-166.

Sulaiman, S. and Mitchell, F. (2005) Utilising a typology of management accounting change: An empirical analysis, Management Accounting Research, 16, pp. 422-437.

Vaivio, J. (1999) Exploring a non-financial management change, Management Accounting Research, 10, pp. 409-437.

Williams, J.J. and Seaman, A.E. (2001) Predicting Change in Management Accounting Systems: National Culture and Industry Effects, Accounting, Organization and Society, 26, p. 443-460. 